\title{
EFFECTS OF SHORT TERM EXPOSURE TO THERAPEUTIC LEVELS OF FORMALIN ON HEALTH STATUS OF NILE TILAPIA, OREOCHROMIS NILOTICUS
}

\author{
H. A. C. C. PERERA and A. PATHIRATNE* \\ Department of Zoology, University of Kelaniya, Kelaniya.
}

(Accepted: 28 January 2005)

\begin{abstract}
Although formalin is commonly used as a chemotherapeutant in fish culture, ill health conditions in some fish species at therapeutic levels have been reported. The present study was conducted to investigate the effects of short term formalin bath treatments on the health status of fingerlings and sub-adults of Oreochromis niloticus, a culturable food fish in Sri Lanka. Health status of the fish was assessed in comparison to the control fish by monitoring survival, respiratory rates, erythrocytic indices in blood and histology of gill and liver tissues after one hour exposure to different concentrations of formalin followed by transfer to clean water for 7 days. No significant alterations with respect to the parameters studied were observed in the fingerlings exposed to $50 \mathrm{mg} \mathrm{L}^{-1}$ formalin. Upon transfer to freshwater, formalin induced alterations in oxygen consumption rates and erythrocytic indices in the blood returned to normal levels after 7 days and histopathological changes in gill and liver tissues were observed to be restored to some degree. Results revealed that formalin could be used at the level of $50 \mathrm{mg}$ $\mathbf{L}^{-1}$ for 1 hour for therapeutic purposes without undue harm to $O$. niloticus fingerlings but special caution should be taken when high concentrations of formalin are used in culturing this species.
\end{abstract}

Key words: Chemotherapeutant, formalin, Nile tilapia, Oreochromis niloticus, toxicity

\section{INTRODUCTION}

Formalin has been recognized as an effective chemotherapeutant for controlling external parasitic and fungal infections in cultured fish. ${ }^{1-4}$ Fish infected with protozoan and monogenean ectoparasites are commonly treated with $150 \mathrm{mg}$ $\mathrm{L}^{-1}-250 \mathrm{mg} \mathrm{L}^{-1}$ formalin bath for 1 hour. ${ }^{1-3}$ Formalin concentrations between $50 \mathrm{mg} \mathrm{L}^{-1}$ to 60 $\mathrm{mg} \mathrm{L}^{-1}$ are also used as a 30 minute short bath for controlling external infections in cultured fish. ${ }^{2,3}$ Lower concentrations of formalin $\left(25 \mathrm{mg} \mathrm{L}^{-1}-50\right.$ $\mathrm{mg} \mathrm{L}^{1}$ ) have also been used for prolonged bath treatments to control protozoan and monogenean parasites of cultured fish. ${ }^{1,3,4}$

Formalin is a reducing agent which can remove oxygen from water ${ }^{5}$ and form methylene cross-links in proteins. ${ }^{6}$ Some fish species, especially salmonids are particularly sensitive to formalin. Mortality and ill health conditions have been reported in salmonid fish following therapeutic treatments. ${ }^{7-9}$ Although formalin is heavily used as a chemotherapeutant in tropical aquaculture, ${ }^{2,3}$ few studies have been conducted to evaluate its toxic effects on tropical fish. Continuous exposure of Nile tilapia to sublethal concentrations of formalin for several weeks had induced anaemic and hyperglycemic conditions ${ }^{10}$ and significant growth reduction. ${ }^{11}$ Exposure of taste buds to formalin had suppressed the gustatory neural response in Nile tilapia. ${ }^{12}$ The objective of the present study was to determine the effects if any, of short term exposure to therapeutic levels of formalin, on the health status of fingerlings and sub-adults of Nile tilapia, Oreochromis niloticus. Health status of the fish was evaluated by monitoring survival, respiratory rates, erythrocytic indices of the blood and histological structure of gill and liver tissues of the exposed fish and the control fish. Choice of $O$. niloticus as the test fish species was based on their importance in aquaculture in Asian countries, especially in Sri Lanka.

\section{METHODS AND MATERIALS}

Experimental fish: Healthy, Nile tilapia, $O$. niloticus fingerlings (5- $5.5 \mathrm{~g}$ in body weight and $4.8-5 \mathrm{~cm}$ in total length) and sub-adults (100-105 g in body weight and $13-14.5 \mathrm{~cm}$ in total length) were collected from the Udawalawa fish breeding station, National Aquaculture Development Authority, Sri Lanka. Fish were acclimated separately to the laboratory conditions in aquaria filled with aged aerated tap water under natural photoperiod for $14 \mathrm{~d}$. During the acclimation period, fish were fed once daily with commercially prepared food pellets at $2 \%$ of the body weight. 
Formalin treatment: Separate baths with formalin concentrations of $50 \mathrm{mg} \mathrm{L}^{-1}, 150 \mathrm{mg} \mathrm{L}^{-1}$ and 250 $\mathrm{mg} \mathrm{L}^{-1}$ were prepared in glass aquaria using commercially available $40 \%$ formaldehyde solution and aged tap water $(68 \mathrm{~L})$. Glass aquaria filled with aged tap water only served as controls. Fingerlings were exposed to formalin concentrations at $50 \mathrm{mg} \mathrm{L}^{-1}, 150 \mathrm{mg} \mathrm{L}^{-1}$ and 250 $\mathrm{mg} \mathrm{L} \mathrm{L}^{-1}$ or to aged tap water for $1 \mathrm{~h}$ in the aquaria at stocking densities 25 fingerlings $/ 68 \mathrm{~L}$. Subadults were exposed to formalin at $150 \mathrm{mg} \mathrm{L}^{-1}$ and $250 \mathrm{mg} \mathrm{L}^{-1}$ or to aged tap water for $1 \mathrm{~h}$ in the aquaria at stocking densities 10 sub-adults/ $68 \mathrm{~L}$. There were three replicate aquaria for each formalin treatment both in the case of fingerlings and the sub-adults and for the respective controls without formalin.

Younger stages of fish were more sensitive to chemical toxicity than older stages. ${ }^{13}$ Since the fingerlings were not affected at $50 \mathrm{mg} \mathrm{L}^{-1}$ formalin exposure, sub-adults were not tested at this concentration. Dissolved oxygen concentration, $\mathrm{pH}$ and temperature of the water in the control and treatment aquaria were measured during the period of exposure using water quality meters (HACH company, USA).

Respirometry and haematology: During the $1 \mathrm{~h}$ exposure period, the general behaviour (such as activity, swimming patterns) and the opercular movement rates of the fish in the treatment and controls were monitored at $15 \mathrm{~min}$ intervals. After $1 \mathrm{~h}$ of exposure, the oxygen consumption rates of the fish were measured using static respirometers as described by Cech. ${ }^{14}$ The oxygen concentrations of water in the reference and experimental respirometers were determined by the Winkler method. ${ }^{15}$ Blood samples obtained by puncturing the caudal vessels of the fish were tested immediately for haematological studies. Total erythrocyte counts were made using an improved Neubar ruling hemocytometer and modified Shaw's solution for dilution. ${ }^{16}$ Haematocrit values were obtained using heparinized microhaematocrit tubes and centrifuging for $5 \mathrm{~min}$ in a micro-haematocrit centrifuge. Haemoglobin concentration was determined by the cyanohaemoglobin method using diagnostic kits from Sigma Diagnostics, USA.
Histology: Gill and liver tissues of the treated and control fish were preserved in $10 \%$ neutral buffered formalin and embedded in paraffin wax following the standard procedures. ${ }^{17}$ Sections of the gill and liver tissues were cut at 5-7 $\mu \mathrm{m}$ thickness and stained with haematoxylin and eosin. ${ }^{17}$

Recovery studies: Ten fish from each test aquarium were transferred to aged tap water and then, oxygen consumption rates, erythrocytic indices and histological structure of the gills and liver were determined after $7 \mathrm{~d}$ to assess whether formalin induced changes could be restored within a short period of time.

Statistical analysis: Data obtained from fish samples from replicates of each treatment were pooled when analyzing the data. Data for each parameter were compared using one way analysis of variance (ANOVA). Where differences were significant, differences among the mean parameters of fish exposed to formalin and those from the controls were compared using Scheffe's test. ${ }^{18}$ The accepted level of significance was $\mathrm{P}<0.05$. Initially, the specific parameters of fish among replicate aquaria for each formalin treatment were statistically analysed using ANOVA. Where no significant difference was found among the replicates, the data obtained from fish samples of each replicate aquarium for a specific parameter were pooled and analyzed statistically.

\section{RESULTS}

Marked behavioural changes such as erratic swimming movements, partial or complete loss of equilibrium were seen in the fingerlings and subadults during the hour of exposure to $150 \mathrm{mg} \mathrm{L}^{-1}$ and $250 \mathrm{mg} \mathrm{L}^{-1}$ formalin. Opercular movement rates of the fish increased upon transfer to aquaria containing $150 \mathrm{mg} \mathrm{L}^{-1}$ and $250 \mathrm{mg} \mathrm{L}^{-1}$ formalin in a concentration dependent manner but returned to normal towards the end of the $1 \mathrm{~h}$ exposure period (Table 1). During the exposure period of one hour, the temperature (range $28.1-28.4^{\circ} \mathrm{C}$ ), $\mathrm{pH}$ (range $7.40-7.61)$ and dissolved oxygen concentration (range $5.35-6.47 \mathrm{mg} \mathrm{L}^{-1}$ ) of the water in each of 
the formalin treated aquaria were not significantly different from those of the control aquaria.

The oxygen consumption rates of both fingerlings and sub-adults exposed to formalin for a period of one hour were significantly lower than those of the control fish (Table 2). Oxygen consumption rates of the fingerlings exposed to $150 \mathrm{mg} \mathrm{L}^{-1}$ formalin were lower than those exposed to $250 \mathrm{mg} \mathrm{L}^{-1}$. Erythrocyte count, haematocrit and haemoglobin levels of the fingerlings exposed to $50 \mathrm{mg} \mathrm{L}^{-1}$ formalin were not significantly different from those from the controls. However when fingerlings and sub adults were exposed to 150 $\mathrm{mg} \mathrm{L}^{-1}$ and $250 \mathrm{mg} \mathrm{L}^{-1}$ formalin, these parameters were significantly higher than those from controls. Formalin induced alterations in oxygen consumption rates and the haemoglobin levels in blood returned to normal seven days after transfer of fish to aged tap water. (Table 3). Erythrocyte counts in the blood of sub-adults exposed to all tested concentrations of formalin restored to normal levels on the seventh day of post exposure. The erythrocyte counts in blood of fingerlings exposed to $250 \mathrm{mg} \mathrm{L}^{-1}$ formalin remained elevated even after the seventh day of post exposure.
Prominent histopathological changes in the gill tissues viz. hyperplasia and hypertrophy of cells, epithelial separations and club shaped deformities were observed in the fish after exposure to $150 \mathrm{mg} \mathrm{L}^{-1}$ and $250 \mathrm{mg} \mathrm{L}^{-1}$ formalin. Histopathological changes in the gills of fingerlings exposed to $250 \mathrm{mg} \mathrm{L}^{-1}$ formalin were more severe ( Figure 1). Vacuolated areas in the liver cells of the fingerlings exposed to $250 \mathrm{mg} \mathrm{L}^{-1}$ formalin (Figure 2) were also observed.

Histopathological changes in gill tissues and liver tissues of the fish were observed to recover to some degree after a recovery period of 7 days. All sub-adults exposed to the tested concentrations of formalin $\left(150 \mathrm{mg} \mathrm{L}^{-1}\right.$ and 250 $\mathrm{mg} \mathrm{L}^{-1}$ ) and all fingerlings exposed to the concentrations of $50 \mathrm{mg} \mathrm{L}^{-1}$ and $150 \mathrm{mg} \mathrm{L}^{-1}$ survived up to the end of the seven day period whereas the survival of the fingerlings exposed to $250 \mathrm{mg} \mathrm{L}^{-1}$ formalin was $92 \%$. Mortality of fingerlings exposed to $250 \mathrm{mg} \mathrm{L}^{-1}$ formalin occurred on the fourth day of post exposure.

\section{DISCUSSION}

Formalin is a reducing agent and cause reduction of oxygen level in water. ${ }^{5}$ Therefore, formalin

Table 1: Opercular movement rates of $O$. niloticus during the one hour exposure period to various concentrations of formalin

\begin{tabular}{lcccc}
\hline \multirow{2}{*}{ Treatment } & \multicolumn{3}{c}{ Opercular movement rate $\left(\mathrm{min}^{-1}\right)$} \\
\cline { 2 - 5 } & & & & \\
& & & $\mathrm{m} \mathrm{min}$ & $60 \mathrm{~min}$ \\
\hline Fingerlings & $61 \pm 0.41 \mathrm{a}$ & $61 \pm 0.34 \mathrm{a}$ & $61 \pm 0.44 \mathrm{a}$ & $61 \pm 0.32 \mathrm{a}$ \\
Control & $63 \pm 0.86 \mathrm{a}$ & $62 \pm 0.58 \mathrm{a}$ & $63 \pm 0.66 \mathrm{a}$ & $63 \pm 0.20 \mathrm{a}$ \\
$50 \mathrm{mg} \mathrm{L}^{-1}$ formalin & $66 \pm 0.66 \mathrm{~b}$ & $74 \pm 0.58 \mathrm{~b}$ & $78 \pm 0.52 \mathrm{~b}$ & $65 \pm 1.03 \mathrm{a}$ \\
$150 \mathrm{mg} \mathrm{L}^{-1}$ formalin & $71 \pm 0.71 \mathrm{c}$ & $75 \pm 1.16 \mathrm{~b}$ & $76 \pm 1.07 \mathrm{~b}$ & $67 \pm 0.68 \mathrm{~b}$ \\
$250 \mathrm{mg} \mathrm{L}^{-1}$ formalin & & & \\
Sub adults & $68 \pm 0.51 \mathrm{a}$ & $67 \pm 0.41 \mathrm{a}$ & $67 \pm 0.58 \mathrm{a}$ & $66 \pm 0.88 \mathrm{a}$ \\
Control & $74 \pm 1.43 \mathrm{~b}$ & $77 \pm 0.71 \mathrm{~b}$ & $79 \pm 0.58 \mathrm{~b}$ & $68 \pm 0.92 \mathrm{a}$ \\
$150 \mathrm{mg} \mathrm{L}^{-1}$ formalin & $74 \pm 1.34 \mathrm{~b}$ & $80 \pm 2.87 \mathrm{~b}$ & $79 \pm 1.52 \mathrm{~b}$ & $67 \pm 1.16 \mathrm{a}$ \\
\hline
\end{tabular}

Data are presented as mean \pm S.E. for 5 treated fish and 10 control fish. For each column with respect to each stage of fish, means followed by the different letters are significantly different from each other. (ANOVA, Scheffe's test $\mathrm{p}<0.05$ ) 
Table 2: Oxygen consumption rates and erythrocytic indices of $O$. niloticus after one hour exposure to therapeutic levels of formalin

\begin{tabular}{|c|c|c|c|c|}
\hline Treatment & $\begin{array}{c}\text { Oxygen } \\
\text { consumption } \\
\text { rate }\left(\mathrm{mg} \text { of } \mathrm{O}_{2} \mathrm{~h}^{-1}\right)\end{array}$ & $\begin{array}{c}\text { Erythrocyte } \\
\text { count } \times 10^{4}\left(\mathrm{~mm}^{-3}\right)\end{array}$ & $\begin{array}{c}\text { Haematocrit } \\
(\%)\end{array}$ & $\begin{array}{l}\text { Haemoglobin } \\
\qquad\left(\mathrm{g} \mathrm{dL}^{-1}\right)\end{array}$ \\
\hline
\end{tabular}

\section{Fingerlings}

Control

$50 \mathrm{mg} \mathrm{L}^{-1}$ formalin

$150 \mathrm{mg} \mathrm{L}^{-1}$ formalin

$250 \mathrm{mg} \mathrm{L}^{-1}$ formalin

$$
\begin{array}{r}
5.93 \pm 0.11 \mathrm{a} \\
5.54 \pm 0.25 \mathrm{a} \\
3.39 \pm 0.32 \mathrm{~b} \\
4.63 \pm 0.18 \mathrm{c}
\end{array}
$$

$122.8 \pm 1.2 \mathrm{a}$

$124.4 \pm 0.9 \mathrm{a}$

$137.5 \pm 1.6 \mathrm{~b}$

$151.5 \pm 2.7 \mathrm{c}$
$10.2 \pm 0.2 \mathrm{a}$

$11.0 \pm 0.2 \mathrm{a}$

$12.6 \pm 0.4 \mathrm{~b}$

$14.3 \pm 0.3 \mathrm{c}$
$5.32 \pm 0.05 \mathrm{a}$

$5.54 \pm 0.08 \mathrm{a}$

$6.33 \pm 0.11 \mathrm{~b}$

$8.12 \pm 0.31 \mathrm{c}$

\section{Sub adults}

\section{Control}

$150 \mathrm{mg} \mathrm{L}^{-1}$ formalin

$250 \mathrm{mg} \mathrm{L}^{-1}$ formalin
$26.60 \pm 0.45 a$
$22.26 \pm 0.48 b$
$23.59 \pm 0.39 b$

$157.05 \pm 1.80 \mathrm{a}$

$16.7 \pm 0.5 a$

$7.09 \pm 0.25 a$

$231.20 \pm 4.03 \mathrm{~b}$

$23.6 \pm 0.6 \mathrm{~b}$

$8.28 \pm 0.24 \mathrm{~b}$

$234.10 \pm 8.43 \mathrm{~b}$

$24.4 \pm 0.7 \mathrm{~b}$

$10.58 \pm 0.18 \mathrm{c}$

Data are presented as mean \pm S.E. for $15-30$ fish. For each column with respect to each stage of fish, means followed by the different letters are significantly different from each other. (ANOVA, Scheffe's test $p<0.05$ )

Table 3: Oxygen consumption rates and erythrocytic indices of formalin treated $O$. niloticus after seven days in clean water

\begin{tabular}{ccccc}
\hline Treatment & $\begin{array}{c}\text { Oxygen } \\
\text { consumption } \\
\text { rate }\left(\mathrm{mg} \mathrm{of} \mathrm{O}_{2} \mathrm{~h}^{-1}\right)\end{array}$ & $\begin{array}{c}\text { Erythrocyte } \\
\text { count } \mathrm{x} 10^{4}\left(\mathrm{~mm}^{-3}\right)\end{array}$ & $\begin{array}{c}\text { Haematocrit } \\
(\%)\end{array}$ & $\begin{array}{c}\text { Haemoglobin } \\
\left(\mathrm{g} \mathrm{dL}^{-1}\right)\end{array}$ \\
\hline
\end{tabular}

\section{Fingerlings}

Control

$\begin{array}{rl}5.65 \pm 0.09 \mathrm{a} & 123.0 \pm 1.2 \mathrm{a} \\ 5.49 \pm 0.17 \mathrm{a} & 126.5 \pm 1.9 \mathrm{a} \\ 6.01 \pm 0.22 \mathrm{a} & 124.6 \pm 1.8 \mathrm{a} \\ 5.52 \pm 0.18 \mathrm{a} & 136.9 \pm 3.5 \mathrm{~b}\end{array}$

$10.0 \pm 0.1 \mathrm{a}$
$11.0 \pm 0.3 \mathrm{a}$
$11.1 \pm 0.4 \mathrm{a}$
$12.1 \pm 0.3 \mathrm{~b}$

$5.25 \pm 0.04 \mathrm{a}$

$50 \mathrm{mg} \mathrm{L}^{-1}$ formalin

$52 \pm 0.18 a$

$136.9 \pm 3.5 \mathrm{~b}$

$12.1 \pm 0.3 \mathrm{~b}$

$5.20 \pm 0.06 \mathrm{a}$

$5.19 \pm 0.32 \mathrm{a}$

$250 \mathrm{mg} \mathrm{L}^{-1}$ formalin

\section{Sub adults}

Control

$150 \mathrm{mg} \mathrm{L}^{-1}$ formalin

$250 \mathrm{mg} \mathrm{L}^{-1}$ formalin
$26.74 \pm 0.42 \mathrm{a}$

$27.44 \pm 1.02 \mathrm{a}$

$27.02 \pm 0.86 \mathrm{a}$
$168.3 \pm 2.7 \mathrm{a}$

$166.3 \pm 2.1 \mathrm{a}$

$173.0 \pm 1.7 \mathrm{a}$
$17.2 \pm 0.4 \mathrm{a}$

$19.1 \pm 0.1 \mathrm{~b}$

$19.2 \pm 0.1 b$

Data are presented as mean \pm S.E. for $8-30$ fish. For each column with respect to each stage of fish, means followed by the different letters are significantly different from each other. (ANOVA, Scheffe's test $p<0.05$ )

treatment in fish culture, should always be donewith close monitoring of oxygen levels of the water. In the present study, the dissolved oxygen levels in water remained within favourable limits for the fish. Behavioural changes and high opercular movement rates of the fish during the one hour exposure to $150 \mathrm{mg} \mathrm{L}^{-1}$ or $250 \mathrm{mg} \mathrm{L}^{-1}$ formalin indicate the responses of the fish to stress caused by formalin. The higher opercular movement rates of the fish may be an attempt of the exposed chemically stressed fish to get more oxygen from the water. ${ }^{5}$ 


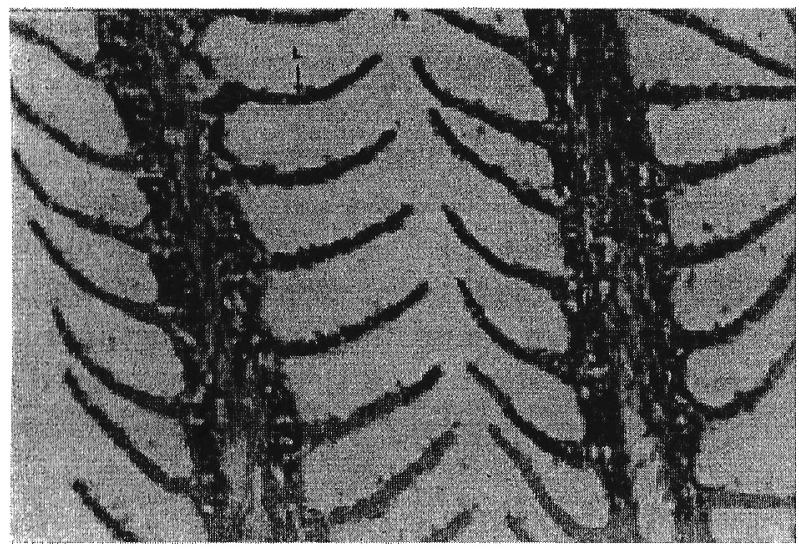

(a)

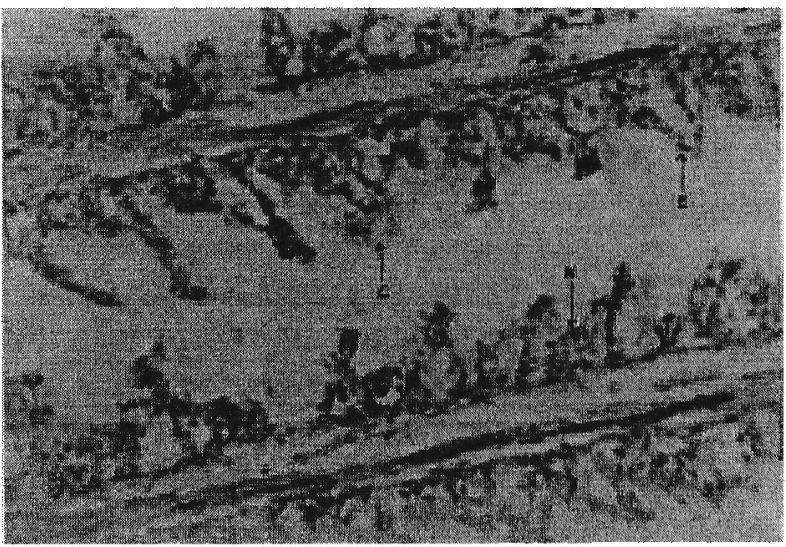

(b)

Figure 1: (a) Gill filaments of control fingerlings of $O$. niloticus showing normal histological structure (X 200) (b) Gill filaments of the fingerlings exposed to $250 \mathrm{mg} \mathrm{L}^{-1}$ formalin for 1 hour (X 200)(L - gill lamellae, E - Epithelial separation, H-hyperplasia, C- club shaped deformities).

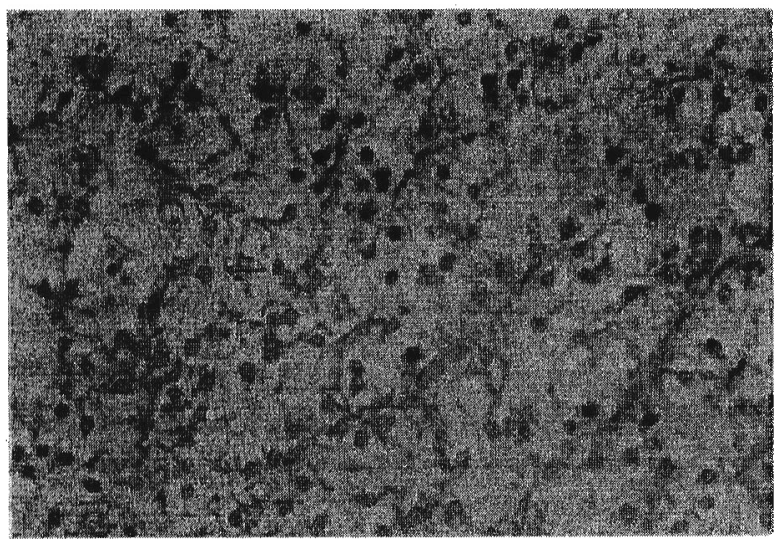

(a)

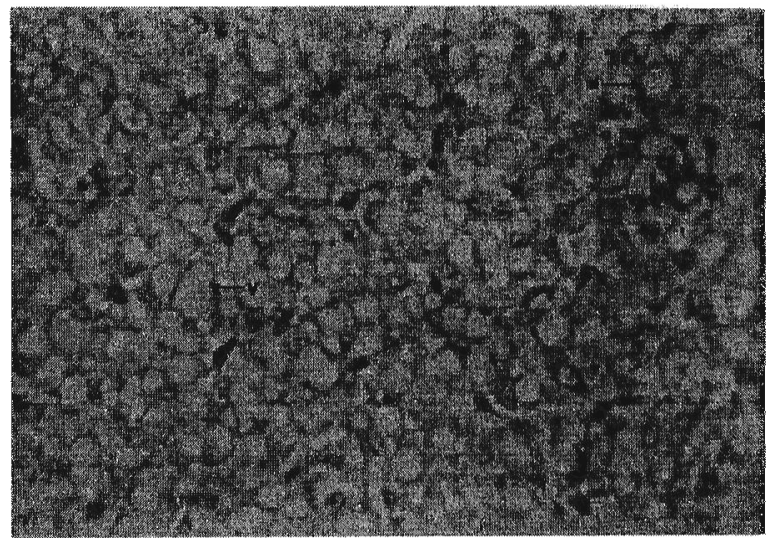

(b)

Figure 2: (a) Section of liver of control fingerlings of $O$. niloticus showing normal histological structure (X 400) (b) section of a liver of the fingerlings exposed to $250 \mathrm{mg} \mathrm{L}^{-1}$ formalin for 1 hour (X 400 ) (H - hepatocytes, V - vacuolated areas).

Formalin is used in concentrations between $50-60 \mathrm{mg} \mathrm{L}^{-1}$ as a short bath (30.minutes) or as a prolonged bath for controlling external infections in cultured fish. ${ }^{2,3}$ One hour exposure of fish to higher concentrations of formalin (150 $250 \mathrm{mg} \mathrm{L}^{-1}$ ) is recommended for effective control of heavy infections of ectoparasitic protozoans and Monogeneans. ${ }^{1-3}$ Results of this study indicates that exposure to $50 \mathrm{mg} \mathrm{L}^{-1}$ formalin for one hour had no significant health effects on the fingerlings of Nile tilapia. Since the fingerlings were not affected by an hour exposure to $50 \mathrm{mg} \mathrm{L}^{-1}$ of formalin, no adverse effects could be expected in sub-adults if they were exposed to $50 \mathrm{mg} \mathrm{L}^{-1}$ formalin for $1 \mathrm{~h}$. However the highest concentration recommended for effective control of ectoparasites on fish, $250 \mathrm{mg} \mathrm{L}^{-1}$ formalin for 1 hour had decreased the oxygen consumption rates of fingerlings and sub-adults of Nile tilapia and induced histopathological changes in the gills and liver of the fish.

Formalin induced histopathological changes in the gills of salmonid fish have been reported previously. Rainbow trout (Salmo gairdneri) when exposed to $167-250 \mathrm{mg} \mathrm{L}^{-1}$ formalin for 1 hour 
had resulted in severe histopathological changes in gill epithelium. ${ }^{7}$ Previous studies have found necrosis, hypertrophy and epithelial separation in the gills of rainbow trout exposed to $200 \mathrm{mg} \mathrm{L}^{-1}$ formalin. ${ }^{8}$ Results of the present study of Nile tilapia are in agreement with these findings. In the present study, oxygen consumption rates of fish exposed to $150-250 \mathrm{mg} \mathrm{L}^{-1}$ of formalin decreased significantly in comparison to control levels after one hour exposure. This could be attributed to the damage to gill tissues of the fish by formalin exposure. After one hour exposure period to $250 \mathrm{mg} \mathrm{L}^{-1}$ formalin, vacuolated areas in the liver tissues were observed in the fingerlings. Some shrinkage of liver cells has been observed in rainbow trout exposed to $200 \mathrm{mg} \mathrm{L}^{-1}$ formalin for one hour. ${ }^{19}$

In fish, red blood cell counts and haematocrit levels increase in response to low oxygen environments. The observed increase in erythrocytic indices in the blood of the fingerlings and sub-adults exposed to $150 \mathrm{mg} \mathrm{L}^{-1}$ and $250 \mathrm{mg}$ $\mathrm{L}^{-1}$ formalin could be a physiological response to the increase in oxygen demand of the body resulting from inefficient oxygen movement through the damaged gill epithelium. It appears that haematopoetic tissues of the formalin exposed fish release more erythrocytes to the circulating blood in response to increase in oxygen demand of the body.

Seven days after transfer of formalin exposed fish to aged tap water, the damaged gill tissues showed signs of repair and oxygen consumption rates and haemoglobin content in the blood returned to the normal levels. This fast recovery may be due to rapid loss of formalin from their tissues. It was reported that a tropical fish Clarias batrachus retained a considerable amount of formaldehyde following 24 hours exposure to formalin at $50-100 \mathrm{mg} \mathrm{L}^{-1}$ but there was no formaldehyde detected after keeping the exposed fish in clean running water for 24 hours. It has been reported that Nile tilapia fingerlings exposed to sublethal concentrations of formalin (1.56 - $25 \mathrm{mg} \mathrm{L}^{-1}$ ) for 12 weeks had reduced weight gain, anaemia and hyperglycemia in comparison to the controls. ${ }^{10,11}$ This indicates that even the lower doses of formalin could adversely affect the fish if it is used repeatedly.
In conclusion, the present study revealed that formalin could be used at the level of $50 \mathrm{mg} \mathrm{L}^{-1}$ for one hour for therapeutic purposes of fingerling stage of Nile tilapia without undue harm to the fish. Even though, changes induced by exposure to the levels $150 \mathrm{mg} \mathrm{L}^{-1}$ and $250 \mathrm{mg} \mathrm{L}^{-1}$ formalin were reparable to some degree, precautions should be taken when using high concentrations of formalin as a short term therapeutant in Nile tilapia culture, especially for the fingerling stage.

\section{Acknowledgement}

Thanks are due to Mr. Upali Wanigasekara, for assistance with the histological preparations and photomicrographs.

\section{References}

1. Roberts R.J.(1978). Fish Pathology. p. 318 Baillier Tindall. London.

2. Subasinghe R.P. (1992). The use of therapeutic agents in aquaculture in Sri Lanka. In:Diseases in Asian Aquaculture I (Eds. M. Sharrif, R.P. Subasinghe \& J. R. Arthur.) pp. 547-553. Fish Health Section, Asian Fisheries Society, Manila.

3. Tonguthai K. \& Chanratchakool P. (1992). The use of chemotherapeutic agents in aquaculture in Thailand. In: Diseases in Asian Aquaculture $I$ (Eds. M. Sharrif, R.P. Subasinghe \& J. R. Arthur) pp. 555-565. Fish Health Section, Asian Fisheries Society, Manila.

4. Paperna I. (1996), Parasites, infections and diseases of fishes in Africa: an update. Food and Agricultural Organization of the United Nations. CIFA Technical paper 31, Rome.

5. Post G. (1987). Text book of Fish Health. p. 288. TFH Publications Inc. New Jersey,USA.

6. Chang C. C. \& Gershwin M. E. (1992). Perspectives on formaldehyde toxicity: separating fact from fantasy. Regulatory Toxicology and Pharmacology 6:150-160.

7. Smith C. E. \& Piper R.G.(1972). Pathological effects of formalin treated rainbow trout (Salmo gairdneri). Journal of the Fisheries Research Board of Canada 29(3): 328-329. 
8. Wedemeyer G. \& Yasutake W. T. (1974). Stress of formalin treatment in juvenile spring Chincook salmon and steel head trout. Journal of the Fisheries Research Board of Canada 31: 179-184.

9. Ross L. G., Ward K.M.H. \& Ross B. (1985). The effects of formalin, malachite green and suspended solids on the respiratory activity of rainbow trout, Salmo gairdneri Richardson Aquaculture and Fisheries Management $16: 129$ 138.

10. Omoregie E., Eseyin T.G. \& Ofojekwu P.C. (1994). Chronic effects of formalin on erythrocyte counts and plasma glucose of the Nile tilapia, Oreochromis niloticus. Asian Fisheries Science 7: 1-6.

11. Omoregie E., Ofojekwu P.C. \& Amali E.I. (1998). Effects of sub-lethal concentrations of formalin on weight gain in the Nile tilapia, Oreochromis niloticus (Trewavas). Asian Fisheries Science 10: 323-327.

12. Yacoob S. Y., Anraku K., Archdale M. V., Matsuoka T. \& Kiyohara S. (2002). Exposure of taste buds to potassium permanganate and formalin suppresses the gustatory neural response in the Nile tilapia Oreochromis niloticus (Linnaeus). Aquaculture Research 33: 445-453.

13. Rand G. M. \& Petrocelli S. R. (1985). Fundamentals of Aquatic Toxicology. p. 666 Taylor \& Francis, Bristol,UK.
14. Cech J.J.(1990). Respirometry. In: Methods for Fish Biology.(Eds. C.B.Schreck \& P.B.Moyle) pp. 335-362. American Fisheries Society. Maryland, USA.

15. Taras M.J., Greenberg A.E., Hoak R. D. \& Rand M. C. (1971). Standard Methods for the Examination of Water and Waste-water. p. 874. American Public Health Association, Washington D.C.

16. Houstan A.H. (1990). Blood and circulation. In: Methods for Fish Biology (Eds. C.B. Schreek \& P.B.Moyle) pp.273-334. American Fisheries Society. Maryland, USA.

17. Bucke D. (1989). Histology. In: Methods for the Microbial Examination of Fish and Shellfish. (Eds. B. Austin \& D. A. Austin) pp. 69-97. Ellis Horwood Limited. West Sussex, UK.

18. Zar J. H. (1999). Biostatistical Analysis. p. 663 Prentice Hall, New Jersey, USA.

19. Williams H. A. \& Wootten R. (1981). Some effects of therapeutic levels of formalin and copper sulphate on blood parameters in rainbow trout. Aquaculture 24: 341-353.

20. Subasinghe R. P. \& Yusoff F. M. (1993). Retention of formaldehyde in the tissues of two tropical fish species following exposure to the therapeutic levels. Aquaculture and Fisheries Management 24: 693-697. 